\title{
Theological education and the COVID-19 pandemic in Sub-Saharan Africa: A Malawian perspective
}

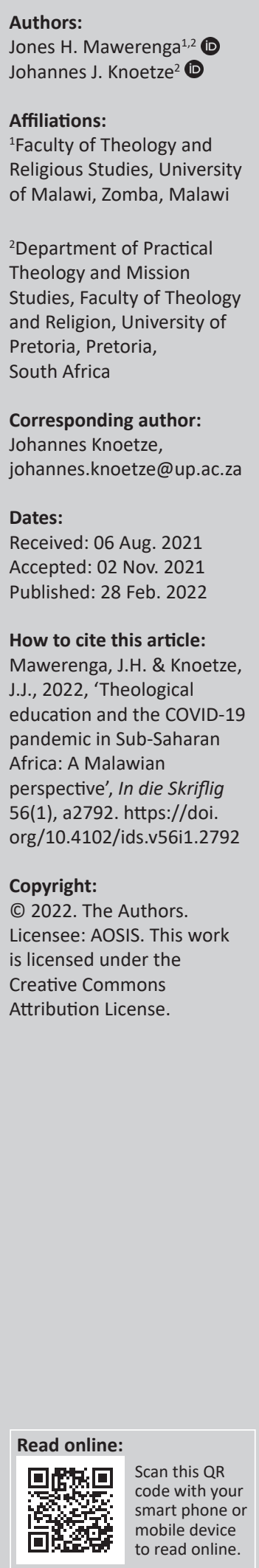

The coronavirus disease 2019 (COVID-19) pandemic has brought a unique disruptive moment of unprecedented proportions in world history affecting all spheres of life. Theological education in Malawi, Sub-Saharan Africa, has not been spared in experiencing the effects of the COVID-19 pandemic. This study argues that the effectiveness of theological education in Africa contributes towards the future of Christianity on the continent, because it serves as a foundation for a vibrant missional church. Nevertheless, the COVID-19 pandemic has provided opportunities for creativity and innovation which could ensure the survival and sustainability of theological education in Africa. It is therefore crucial to critically reflect on how the provision of theological education in Malawi in particular, and in Sub-Saharan Africa, in general, can be sustained during the uncertain and challenging times when the COVID-19 pandemic is devastating the African continent and the entire world. This article investigated the challenges and opportunities for theological education in Malawi in view of the ongoing COVID-19 pandemic. In view of this, the following five objectives emerged: (1) to evaluate the Malawi government's response to the COVID-19 pandemic; (2) to discuss the history and importance of theological education in Africa; (3) to examine the challenges of theological education in Malawi in view of the ongoing COVID-19 pandemic; and (4) to assess the prospects of theological education in Malawi in view of the ongoing COVID-19 pandemic. A qualitative research methodology was used, namely a literature review and interviews with members of the faculty of theological institutions in Malawi. Six main findings were established: First, the COVID-19 pandemic has presented both challenges and opportunities for theological education in Africa. Second, the effectiveness of theological education in Africa has contributed towards the future of Christianity on the continent. Third, the COVID-19 pandemic has challenged the dominant models of theological education in Africa. This entails a shift from face-to-face teaching to online teaching and learning. Fourth, the COVID-19 pandemic has provided opportunities for the sustainability of theological education in Africa. Fifth, theological education has encountered misleading theologies regarding the COVID-19 pandemic. Sixth, theological education has the opportunity of constructing life-giving theologies in Africa. This study has two implications: (1) navigating the changing terrain of theological education in Malawi; and (2) theological education's employment of digital technologies during and post the COVID-19 pandemic.

Contribution: This study has contributed to the discourse of theological education in Africa by providing solutions to the challenges posed by the COVID-19 pandemic.

Keywords: COVID-19; digital technologies; Malawi; pandemic; theological education.

\section{Introduction}

This article discusses the phenomena of theological education and the coronavirus disease 2019 (COVID-19) pandemic in Sub-Saharan Africa with specific reference to Malawi. The aim of this study is to investigate the challenges and opportunities for theological education in Malawi in view of the ongoing COVID-19 pandemic. A qualitative research methodology was employed, namely a literature review and interviews with members of the faculty of various theological institutions in Malawi. This article argues that the effectiveness of theological education in Africa contributes towards the future of Christianity on the continent. However, COVID-19 has disrupted the provision of theological education at many institutions in Sub-Saharan Africa, challenging the dominant models of how theological education is offered and even threatening the existence of some of these theological institutions. At the same time, the COVID-19 pandemic provides opportunities for creativity and innovation which could ensure the survival and sustainability of theological education in Africa. Thus, this article addresses the following areas: (1) the Malawi government's response to the COVID-19 pandemic; (2) the history and importance of theological education in Africa; (3) the challenges of theological education in Malawi in view of the COVID-19 
pandemic; and (4) the opportunities for theological education in Malawi in view of the COVID-19 pandemic. The study has two implications: (1) navigating the changing terrain of theological education in Malawi; and (2) theological education's employment of digital technologies during and post COVID-19 pandemic.

\section{Malawi government's response to the coronavirus disease 2019 pandemic}

Chilora (2020:1) presents that Peter Mutharika, former President of Malawi, declared a COVID-19 national disaster on 20 March 2020, even before any COVID-19 case was reported in the country. Gadabu (2020:1) indicates that the government ordered a closure of schools and universities on 23 March 2020, and banned public gatherings of more than 100 people, which included weddings, funerals, religious congregations, political rallies and government meetings.

The Malawi government started to give daily COVID-19 information updates on television and radio news bulletins as well as in print media. The Minister of Health, Minister of Information and other health officials appeared before the nation to announce the recent developments concerning the COVID-19 pandemic. Updates detailed the spread and devastation caused by the virus, often in graphic detail, with graphs and maps illustrating prevalence rates, and areas and districts of prevalence. Information disseminated focused on the following nine areas: new cases, cumulative confirmed cases, active cases, total recovered, currently admitted in treatment units, new discharges from treatment units, total tests conducted, total deaths, and total vaccinated: first dose and second dose. Attention was also given to prevention measures such as wearing masks to cover mouth and nose, washing hands diligently and frequently using soap or hand sanitisers, maintaining social distancing, avoiding hand greeting, hugging or kissing each other.

Kaponda (2020:2) accounts that President Peter Mutharika confirmed the country's first three cases on 02 April 2020. According to Mutharika, the cases involved a resident of Lilongwe who had travelled to India, one of their relatives and their maid.

Patel et al. (2020:71) argue that Malawi's health sector, which battles the epidemic, is already challenged by inadequate funding, insufficient staffing, dilapidated infrastructure, and lack of essential medicines and equipment. Mandala and Changadeya (2021:1-10) report that Malawi's decrepit healthcare system rendered frontline health personnel incapable of mounting an adequate response to critically ill COVID-19 patients who required ventilation during the peak of the epidemic which was experienced from January to February 2021.

Paul Msoma, a patient who died of COVID-19 related illnesses posted a SOS message on his Facebook page as he was on his deathbed gasping for oxygen to breath at the
Kamuzu Central Hospital (KCH). His cry for help deeply moved Malawians of goodwill to start a fundraising initiative to complement the government's efforts in containing the pandemic (Nyasa Times Reporter 2021). He (Msoma 2021) lamented as follows:

I am in Hospital, diagnosed with COVID-19. The hospital staff are so wonderful, and 1 can see pain in their eyes. Yes, they have oxygen cylinders but, in my case, they can't connect me to the much-needed Oxygen because the whole $\mathrm{KCH}$ has no Oxygen flowmeter. My situation is getting worse and I desperately need oxygen. Anyone who can urgently help out there please! Please! Help by donating this very gadget.

Nyasulu et al. (2021) report that the Malawi government repatriated its citizens who were stranded in South Africa due to lockdown measures imposed in that country. By August 2020, about 5000 returnees from South Africa were registered in Malawi. However, Malawi demonstrated a lack of preparedness of the public systems in responding to the COVID-19 pandemic during the initial phase. Obviously, the lack of proper management of the quarantine measures that were put in place for the returnees led to their subsequent escape from quarantine into their respective villages.

Consequently, this raised fears that the pandemic would spread rapidly because of the contact with people who had recently arrived from South Africa - a country that had recorded more COVID-19 cases in Africa.

Therefore, it is against this background of COVID-19 developments that lead us to the discussion of the history and importance of theological education Africa.

\section{The history and importance of theological education in Africa}

Van der Merwe (2016:559) writes that the history of theological education in Africa can be traced to the coming of the Christian church to the northern parts of Africa. The Christian church produced both martyrs and theologians of great renown such as Athanasius, Clement of Alexandria, Anthony, Pachomius from North Africa, Origen, Tertullian and Augustine (Pobee 2013:15-16).

Vidler (1961:246) postulates that the Western church experienced an unprecedented expansion in the 19th century which resulted into the missionary movement to Africa. During this period both Roman Catholic and Protestant missionaries planted churches in many countries in Africa. Consequently, Africa became the most Christianized continent in the world (Isichei 1995:1).

Amanze (2009:120-121) states that various churches established seminaries or theological colleges to train their personnel as ministers in the parishes, for example Kachebere Major Seminary, St. Peter's Major Seminary, Zomba Theological College (ZTC), Evangelical Bible College of Malawi, Josophat Mwale Theological College, Leonard Kamungu Theological College (LKTC), Assemblies of God 
School of Theology, African Bible College, et cetera. Some universities, that is, University of Malawi, Mzuzu University, Nkhoma University, Malawi Assemblies of God University, Malawi Adventist University, University of Livingstonia, University of Blantyre Synod, Lake Malawi Anglican University, and Catholic University of Malawi have established departments of Theology and Religious Studies (TRS) to specifically offer theological and religious education.

Pobee (2013:18) says that the spread of theological institutions in Africa ranges from university departments and faculties, seminaries, Bible schools to theological education by extension. Moreover, the emergence of the Pentecostal charismatic movements in Africa and a vibrant African initiated Christianity have also introduced other models of theological education.

Amanze (2009:120-121) argues that the importance of theological education in Africa is as old as the church itself. Christian churches in Africa were motivated by the Great Commission (Mt 28:18-20) to introduce formal education in the form of Christian schools and theological colleges. Theological colleges eventually became the backbone of Christian evangelism and ministerial formation throughout Africa. Consequently, numerous Bible schools, theological colleges and institutions of theological education by extension were established across Africa.

Matemba (2011:334) argues that theological education in Africa has the mandate to train the clergy and theologians who can effectively engage with public theology in the continent. For instance, in Malawi the Roman Catholic bishops issued a pastoral letter in 1992 which is considered as a catalyst in changing the political landscape from one party dictatorship to the democratic dispensation (Mwandumba 2015:79). Also, Rev. Dr. Lazarus Chakwera's political journey to becoming the sixth president of the Republic of Malawi hinges on the effectiveness of theological education to produce a political theology that engages with the sociosphere (Cotterill 2020:3).

Theological education in Africa is also important because of its contribution to the contemporary discourses on religion and the 2030 Agenda for Sustainable Development. Chitando, Gunda and Togarasei (2020:13) ask a pertinent question: 'What is the role of religion in the development discourses of Africa?' There is a growing consensus that religion (and the values it brings) is critical to the search for sustainable development. Also, Africa is one of the most underdeveloped continents in the world; therefore, the burden for theological education to produce theologians, clergy and well-informed laity that are able to contribute to sustainable development in Africa, cannot be overemphasised.

Wodon (2014:1-4) maintains that theological education in Africa has contributed to the education sector through the establishment of mission schools. The contribution of mission schools is crucial in Africa, particularly at a time when many
Sub-Saharan African countries have failed to achieve the education targets set forth in the 2015 Millennium Development Goals (El Bouhali \& Rwiza 2017:13). Moreover, the 2030 Agenda for Sustainable Development with reference to education as stipulated in Sustainable Development Goal 4, demonstrates the significance of Christian theological education in Africa. In Malawi, there are many places where the only schools available are mission schools; hence, their contribution towards ensuring inclusive and equitable quality education and promoting lifelong learning opportunities for all is very critical (Franco \& Derbyshire 2020:57-68).

Having presented the history and importance of theological education in Africa, this article proceeds to discuss the challenges of theological education in Malawi during the COVID-19 period.

\section{The challenges of theological education in Malawi during the coronavirus disease 2019 pandemic}

The first challenge of theological education in Africa is the countering of misleading theologies' emergence concerning the COVID-19 pandemic. Mwaniki (2020:2) identifies three main misleading theologies on the coronavirus in Africa. First, apocalyptic interpretations that COVID-19 signifies the end of the world and Jesus' return. The Bible counters this claim. Mark 13:32, for example states, 'But of that day and hour no one knows, not even the angels in heaven, nor the Son, but only the Father.' Second, the construction of a misleading eschatology that brings fear for the citizens to partake in the COVID-19 vaccinations. The COVID-19 vaccines are erroneously being equated to the 'mark of the beast, 666' which is mentioned in Revelation 13:18. This can be countered by the fact that interpretation of symbolisms in each phrase in the Book of Revelation has been quite complex and cannot be concluded by such a narrow view. Third, the construction of a misleading theology that claims that COVID-19 has been sent by God as a punishment for world sins and that the only way is to repent and pray day and night, because even medicine will not be found. Hence, theological education in Africa has the responsibility of countering these COVID-19 false theologies through proper accountable exegesis and hermeneutics.

Kaponda (2020:1) states that, on 10 August 2020, Malawi's President, Rev. Dr. Lazarus Chakwera, imposed new COVID-19 restrictions which restricted public gatherings, including religious meetings, to 10 people. However, the religious fraternity in Malawi sternly opposed the new restrictions. For instance, Rev Collin Mbawa, the General Secretary of the General Synod of the Church of Central African Presbyterian (CCAP), reported that the General Assembly met on 12 August 2020 in Lilongwe to deliberate on the government's new COVID-19 restrictions. They unanimously agreed to defy the new COVID-19 restriction capacity of 10 people, and instead maintained its church 
gathering capacity to 100 people while observing all COVID-19 preventative measures (Nations Publications Limited n.d.). This is an example of the church's response to COVID-19 based on misleading theologies. ${ }^{1}$ Therefore, the praxis of the General Synod of the C.C.A.P. in defying the COVID-19 restrictions was erroneous, because it was not lifegiving, life-supporting or life-sustaining in the face of the COVID-19 pandemic (Hutapea 2021:100. Weissman (2021:1) argues that the second wave of the South African variant of COVID-19, which hit Malawi in early January to February 2021, revealed that the church errored in defying the COVID-19 restrictions. If the church had followed the government's restriction measures, then Covid-19 related mortalities could have been significantly reduced.

The second COVID-19 challenge for theological education in Malawi is that the pandemic developed in the context of socio-political turmoil connected with the 2019 tripartite elections and the 2020 Fresh Presidential Elections (FPE) in the country (Tengatenga, Duley \& Tengatenga 2021:1-14). Nyasulu et al. (2020) observe that Malawi's response to the COVID-19 pandemic was initially resisted for two reasons. First, political altercations were augmented by a constitutional court ruling in February 2020 for an FPE on 02 July 2020 due to irregularities observed in the May 2019 elections. However, the election date was changed to 23 June 2020 after the Supreme Court ruled that the election date should be set by parliament. Second, the announcement of the first COVID-19 cases escalated the pre-existing mistrust Malawians had in the then government that was presumed to be running away from holding the FPEs. Consequently, majority of the population's mistrust towards the government negatively affected the efforts of containing the spread of the COVID-19 pandemic.

Kaunga (2020) writes that on 14 April 2020, President Peter Mutharika announced a 21-day nationwide lockdown aimed at preventing the further spread of COVID-19. However, traders, the religious fraternity, civil society organisations, and the general public fiercely criticised the lockdown measures. Consequently, numerous protests were held throughout the country against the lockdown measures. Protesters accused President Peter Mutharika of failing to consider the well-being of ordinary poor Malawians. The demonstrators demanded upkeep money from the government to survive the lockdown period.

Chiuta (2020:1) accounts that Gift Trapence, the chairperson of the Human Rights Defenders Coalition (HRDC), obtained a court injunction on 17 April 2020, restraining the government from implementing the lockdown measures. The injunction was considered a victory for the poor Malawians because the government failed to announce any measures to cushion the poor during the lockdown.

1 The decision was made by the General Synod of the Church of Central African ma Synod, and Livingstonia Synod. The CCAP has many theologians who are trained at Zomb Theological College, Josophat Mwale Theological College, and Livingstonia Mission. The aftermath of the objection by the church to follow COVID-19 restrictions was disaster, as it led to the death of many faithful believers in the church. As a correct theology is life-giving and not life-threatening, we regard the erroneous decision by the CCAP theologians as misleading in view of the ongoing COVID-19 pandemic.
Thus, the existing socio-political crises in the country negatively affected the provision of theological education and the coming of the COVID-19 pandemic exacerbated the problem. However, as already pointed out elsewhere in this article, the burden for theological education to produce a public theology that engages with socio-political challenges in Africa is very crucial (Agang, Forster \& Hendriks 2020:4; De Gruchy 2007:26-41). Agang et al. (2020:10-11) asserts that public theology is needed to set Africa free by holding leaders accountable to biblical standards. African public theology goes beyond merely offering criticism to leaders but goes on to actively engage with socio-political issues arising in our various contexts. This includes working with governments, social institutions, devising policies and laws that enhances the common good.

The third COVID-19 challenge on theological education in Malawi was the closure of all schools and universities on 23 March 2020 (Gadabu 2020). In an effort to curb the spread of COVID-19, governments around the world have moved to suspend face-to-face teaching in schools, affecting some $95 \%$ of the world's student population - the largest disruption to education in history (United Nations 2020). Consequently, most higher learning institutions in Africa are experiencing some challenges in transitioning from the face-to-face mode of education delivery to the online mode of education delivery (Mpungose 2020:1-9).

In Malawi, theological institutions are lagging behind in shifting to online learning because of a lack of access to Internet connectivity. Kayange (2019) observes that the cost of an Internet-enabled device, the power needed to run the device, and Internet data all have costs that must be met by the would-be Internet user. It is therefore very possible that the Internet may be available, meaning that the Internet coverage is there in a certain area, but that the people still do not have Internet access, because it is beyond their financial means

Kayange's assertion can be further buttressed by the Inclusive Internet Index 2020 report which revealed that, out of the 100 countries accessed in the report, Malawi has an overall rank of 97th in the global index and 23rd in Africa. Moreover, the country's efforts to extend Internet access are stymied by low digital literacy, high prices for data (relative to per-capita national income), poor network quality and coverage, and a dearth of relevant content. As a result, usage, even of mobile services, is exceedingly low by international standards (The Inclusive Internet Index 2021). Thus, most theological institutions do not have the Internet facilities to host e-learning, staff are not effectively trained on e-learning delivery, and students have very little or no access to Internet facilities to effectively participate in online learning.

Besides the above-mentioned obstacles to on-line delivery of theological education, theological institutions in Malawi could utilise facilities like WhatsApp or Facebook to reach out to students. In my case at the University of Malawi, I taught two different classes, that is, TRS 113 and TRS 226 
using WhatsApp. The students formed a WhatsApp group to which I was added, and I used to give them lecture notes and then give an audio explanation which was recorded, and students could listen to it at their own time. I also used to respond to questions which students were raised using the WhatsApp forum.

The fourth COVID-19 challenge on theological education in Malawi is the heightened lack of proper resources. Chitando (2009:22-26) argues that theological education in Africa often takes place amid poverty, wars, economic chaos, digital divide and erratic electricity. The shortage of proper library facilities, modern digital technologies and trained personnel challenges the provision of the needed theological education in Africa. Houston (2009:24), however, makes a case for selfsustainability and, in so doing, moves away from models that make theological institutions in Africa dependent on outside resources.

The fifth COVID-19 challenge on theological education in Malawi is the cultural aspects of typical African learning styles. Mkonto (2010:73) observes that students differ from each other in various ways, that is, physically, psychologically and culturally. Consequently, they often have different learning styles. Maluleka (2019:15) maintains that African students who are influenced by the dominant ubuntu cultural aspect prefers to learn in groups and in close fellowship with each other, because the communitarian nature of ubuntu is culturally responsive. Nonetheless, this typical African learning style is against the COVID-19 prevention measures of social distancing and quarantine.

During an interview conducted on 15 October 2021, Mr. Mdoka, a member of the faculty in the TRS department, at the University of Malawi stated that:

[T] he COVID-19 pandemic has disrupted our traditional learning style in which we are used to face-to-face teaching or learning, group assignments, and student discussions in small groups. Now the situation is becoming difficult for students to learn alone just using a gadget instead of seeing a lecturer delivering the lesson in class and also not working in groups with fellow students.

The sixth COVID-19 challenge on theological education in Malawi is the acute humanitarian needs. During an interview conducted on 19 October 2021, Rev. Dr. Chitsulo, the Principal of ZTC commented that:

When the government closed schools on 23 March 2020, all residential students departed for home. However, some international students failed to return, becoming a new kind of refugees. In our case, two Mozambican students together with their families failed to return. Unfortunately, they were also diagnosed with COVID-19. Hence, we had to accommodate them on the campus and ensure that we are providing for their needs and that they have access to healthcare services during this time.

The seventh COVID-19 challenge on theological education in Malawi is the pressing financial challenges faced by theological institutions. During an interview conducted on 17 October 2021, Rev. Fr. Chiutula, the Principal of LKTC mentioned that LKTC had lost income through tuition, local donations, international donations and through other streams such as renting out guesthouses and other facilities on the campus. Consequently, it became increasingly difficult even to maintain both the faculty and staff at the college. Moreover, Rev. Masikamu, former Principal of the Evangelical Bible College (EBCOM) reported during an interview conducted on 14 October 2021 that the situation was worse, because the institution failed to pay salaries for both faculty and staff. Unfortunately, this led to some faculty members resigning from the institution.

Having presented the challenges of theological education in Malawi, this article proceeds to discuss the opportunities for theological education in Malawi.

\section{The opportunities for theological education in Malawi}

The first opportunity for theological education in Malawi is the construction of life-giving, life-supporting or lifeflourishing theologies that enhance life during the pandemic. Chitando et al. (2020:1) argue that church leaders constitute a critical mass of strategically placed individuals who can play a major role in enhancing the effectiveness of the overall response to COVID-19. Thus, theological education can take a leading role in encouraging the church members to comply with all COVID-19 preventative measures and partake in the COVID-19 vaccinations.

Politicians in Malawi acknowledge the positive role played by theological education during the COVID-19 pandemic. Chilora (2020:1) reports that President Peter Mutharika appealed to the religious fraternity to intervene in the fight against the COVID-19 pandemic. He called upon all Malawians of different denominations and faiths to turn to God in times of fear and uncertainty as is done in times of joy and celebration. He further emphasised the need to develop the virtues of love, mercy, truth and courage in facing the challenges posed by the COVID-19 pandemic. This is pertinent to this study, because it demonstrates the crucial role of theological education in spiritual formation that engages with various aspects of the pandemic.

The second opportunity for theological education in Malawi is the construction of theologies that defend Africans' human dignity amid the COVID-19 pandemic. Singh (2020:351) reports that, in early April 2020, a senior French clinician, Jean-Paul Mira, head of intensive care at Cochin Hospital in Paris, insinuated that a vaccine trial testing the efficacy of a tuberculosis vaccine, Bacille Calmette-Guérin (BCG), against COVID-19, should be conducted in Africa. His rationale was simple:

... [T] here are no masks, no treatment, no intensive care, a bit like it is done in some studies on AIDS or among prostitutes. We try things because we know they [sex workers] are highly exposed and they don't protect themselves. (BBC News 2020:n.p.) 
Thus, theological education has an opportunity to condemn this dehumanising statement against Africans' human dignity by utilising theologies of human creation in the image of God (imago Dei).

The third opportunity for theological education in Malawi is addressing the increase of gender-based violence (GBV) during the COVID-19 pandemic. The social and economic stress brought by the COVID-19 pandemic exacerbated preexisting toxic social norms and gender inequality. At the time when half of the world population was in lockdown due to COVID-19, approximately 243 million women and girls between the ages of 15 and 49 had been subjected to sexual and/or physical violence perpetrated by an intimate partner (UN Women 2020). Onyejekwe (2004:34) argues that South Africa is said to have the highest statistics of GBV in the world, including rape and domestic violence. Dlamini (2020) observes that President Cyril Ramaphosa of South Africa described the femicide and GBV scourge, stating that one woman is killed every $3 \mathrm{~h}$. The COVID-19 pandemic and the lockdown were associated with a spike in GBV and femicide. GBV and femicide are twin pandemics to the COVID-19 pandemic. Therefore, theological education has an opportunity for the construction of theologies that uphold women's dignity, rights, equality and bodily autonomy amid the COVID-19 pandemic (Vorster 2006).

The fourth opportunity for theological education in Malawi is the construction of a practical theology that informs both the clergy and the laity during the COVID-19 pandemic. Cahalan (2005:93) statement that theological education has the burden of constructing a practical theology that guides Christians on how to live and ought to live within the idiosyncratic notions of time and place is relevant in view of the COVID-19 pandemic. This can be achieved in at least three ways. First, practical theology's orientation towards the pursuit of wisdom for all Christians to navigate through the COVID-19 scenario. Second, practical theology informs ministers on how to guide and assist Christians to live wisely and faithfully amid the COVID-19 pandemic. Beukes (2020:1-7) calls for a Christian praxis which is able to maintain discipleship through worship, celebration, prayer, fasting, Bible study, meditation, fellowship, mourning, charity, sacrifice, witness, et cetera in compliance with the COVID-19 preventive measures. Third, Kloppers (2020:6) contends that theological education in Africa has the responsibility of constructing a practical theology that counters the spread of fake news concerning COVID-19 and vaccinations.

Theological education in Malawi has the opportunity for constructing a practical theology that is 'missional' during the COVID-19 pandemic in order to ensure that the church does not lose focus on its primary reason of being. Baron and Maponya (2020:3) states that the Covid-19 situation provides the church with an opportunity to shift from being 'inwardlooking to a community that is actively engaged in God's mission in the world'. Beukes (2020:3) explains that the concept missional entails joining God in his mission in the world (missio Dei). It means to be the good news and not just to share it, to express God's grace and love to the hurting world as followers of Jesus Christ, and to shine God's light into the world's darkness. This is God's call to the church in our current context of the COVID-19 pandemic.

Penner (1997:85) argues that practical theology has a binding missionary vocation for the Christian community. He (Penner 1997) states that:

The concept mathetes (disciple) is very important for the understanding of theological education as mission. Here the Judaic tradition and the Christian tradition overlap ... It is prescribed in the Great Commission in Matt.28:18-20 in such a way that didasko (servant) is included in our understanding of the concept ... An outstanding example of comprehensive theological education [in this sense] we find in the student of Gamaliel, the first theologian, apostle to the pagans, and missionary, Paul ... He not only educated the congregations, but left us a practical example for future generations of educators. His great value can be found in his formulation of a [missionary] theology for the young churches, also a theology of education and formation. (pp. 85-89)

Mpofu (2021:1) affirms that practical theology's contribution to God's mission has to constantly adapt to the changing context, particularly in ensuring continued pastoral work amid the COVID-19 pandemic. The COVID-19 situation has forced the church to explore alternatives in at least three ways. First, conducting worship services that comply with COVID-19 prevention measures. Second, being a missional church amid the pandemic's challenges. Third, continuing with pastoral ministry without exposing members to infections through face-to-face meetings.

The fifth opportunity for theological education in Malawi is the use of online teaching and learning methods. Hunter (2020) argues that theological education during the COVID-19 pandemic demands a heavy online investment. He observes that if the pandemic continues for a long time, rendering face-to-face teaching and learning impossible, then a heavy investment into online learning is inevitable. Questions related to faculty training, appropriate platforms, types of online interaction, access to resources, and student formation will guide the process.

Mpungose (2020:3) argues that virtual learning demands that theological educators should consider the possibilities of Internet access and other technological resources for effective learning. As a result, this enables each individual student to gather and share information irrespective of the digital divide challenges faced. In other words, for effective e-learning to occur, even if students are at home, access to the Internet and technological resources should be made available so that they may make connections among themselves and the lecturers, irrespective of the hindrances faced.

In the pursuit of transitioning from face-to-face learning to online learning, providers of theological education also need 
to critically reflect on its limitations. Van Deursen and Van Dijk (2019:357) assert that the digital divide is one of the biggest limitations regarding the employment of educational technology globally. On the one hand, developed countries in the Global North have limited problems with the digital divide. On the other hand, developing countries in the Global South have problems with all three aspects of the digital divide: first, access to the Internet; second, attitude, skills, type of use; third, Internet outcomes or benefits. This suggests that even though institutions of higher learning can provide free access to Wi-Fi within their precincts and students' residences, including free laptops or handsets, there will be some students residing in rental rooms or at home who might not have access to the Internet. Similarly, some students would prefer to use other resources (books), based on their strengths or limitations.

The sixth opportunity for theological education during the COVID-19 pandemic in Malawi was amply explained by Rev. Dr. Chitsulo, the Principal of ZTC, during an interview conducted on 19 October 2021. He said that:

[A]lthough we have closed our institution in compliance to government directive we are still continuing offering theological education through issuing lecture notes, printed study guides and assignments to students with the hope of resuming teaching and exams once the government opens the schools.

Therefore, the provision of theological education continued using the print media technologies which is a traditional teaching-learning method in Africa.

The seventh opportunity for theological education in Malawi during the COVID-19 pandemic is the use of DVDs in the provision of theological education in the country. Fred Morrissette established numerous video Bible schools in Malawi called 'Advanced Christian Training Schools' in 2018. Bishop Eugene Chinunga, Malawi's country coordinator for T-NET International, commented during an interview conducted on 14 October 2021:

T-NET International plays a unique role in providing theological education to pastors. T-Net International's focus is on Finishing the Great Commission of Jesus (Matthew 28:19-20) in each nation of the world by empowering indigenous pastors and church leaders. Our students are continuing with their studies through the use of DVDs. We appreciate this way of learning as it reduces social interaction in a classroom setting and also complies with the rules of social distancing and quarantine.

The eighth opportunity for theological education during the COVID-19 pandemic is to build emotional stability based on Christian virtues. Koenig (2020:2205) insinuates two implications of emotional well-being for the COVID-19 pandemic. First, negative emotions, such as anxiety and fear, increase our susceptibility to the dreaded coronavirus. This is because of the adverse effects on immune functioning that fear, anxiety and psychological distress cause (Coughlin 2012:7). Second, positive emotions help in boosting the immune system. Among Christians, these positive emotions are known as the 'fruit of the spirit' (love, joy, peace, forbearance, kindness, goodness, faithfulness, gentleness, and self-control - Gl 5:22-23).

The virtue of love casts out fear (1 Jn 4:18). Polizzi, Lynn and Perry (2020) opine that the fruit of the Spirit correlates with constructs in positive psychology which serves as important predictors of client resilience and well-being in this COVID-19 context.

The ninth opportunity for theological education during the COVID-19 pandemic is its engagement with the growing challenge of mental health issues in Africa. Semo and Frissa (2020:713) insist that the COVID-19 pandemic is leading to mental health problems in Africa due to disease experience, social distancing, breakdown of social support, stigma and discrimination, grief and mourning for the dead and dying, and job losses. Docrat et al. (2019:706) assert that studies on the mental health consequences of quarantine and lockdowns worldwide have reported marked increases in the risk for depression, anxiety, post-traumatic stress disorder (PTSD), insomnia and suicide. Xiang et al. (2020:228) maintain that theological education has a responsibility of constructing a timely mental health care response in making mental health interventions during the COVID-19 pandemic.

The tenth opportunity for theological education during the COVID-19 pandemic is the networking of various theological institutions in Africa through the Network for African Congregational Theology (NetACT). This is a network of theological institutions in Sub-Saharan Africa, created and directed by these institutions to assist them in preparing leaders for missional congregations through networking and sharing of resources (NetACT n.d.). For instance, the following theological institutions in Malawi are NetACT members: Chancellor College (University of Malawi), Zomba Theological College, African Bible College, Josophat Mwale Theological College (Nkhoma University), and University of Livingstonia.

NetACT organised a theological training workshop for the Central African region during 19-23 August 2019 at African Bible College in Lilongwe, Malawi. Participants came from Malawi, Mozambique, Zambia, Namibia, Zimbabwe and South Africa. The goal of this meeting was to empower theological schools and the church to address the problems of their countries (Mostert 2019). ${ }^{2}$

Mr. Fraser Jackson hosted a 4-day NetACT Internet Portal (NIP) meeting with librarians of theological institutions, alongside the main meeting. The aim of the meeting was to impart skills regarding the use of the NIP (n.d.). The NIP has the following resources: library resources portal, learning and teaching resources portal, formal digital repositories, informal repositories, you tube videos, video and audio chat, and online learning environment.

2 This data is obtained from an email sent by Dr. Nico Mostert, NetAct Program Manager, sent to NetACT members on 20 August 2019. 
Mr. Austin Kajawa, a librarian at the University of Malawi, attended the NIP workshop and made the following comments during an interview conducted on 19 October 2021:

[T] he NIP is a very helpful resource for both faculty and students at the University of Malawi. Students are appreciating this facility because it helps them to do solid research and write very good assignments ... Previously students were limited in their research endeavours due to lack of theological books in our library but now they have unlimited resources through the NIP.

NetACT cognisant of the disruption of theological education in Africa due to the impact of the COVID-19 pandemic organised an online theological education conference on 09 September 2020 (Hendricks 2020). ${ }^{3}$ Therefore, NetACT has made a significant contribution in facilitating the transition of theological education from face-to-face learning to online learning by its affiliated member-theological institutions in Africa.

Therefore, it is evident that theological education's interventions play a crucial role during the pandemic in at least four ways. First, they guide people to find meaning and acceptance amid suffering while engaging in the deepest questions of life (Del Castillo, Biana \& Joaquin 2020:663). Second, they provide counsel, refuge, hope and rejuvenation to many people during the health crisis. Third, they help ministers to effectively administer spiritually and religiously adapted psychotherapies which research has demonstrated to be more effective for wholistic outcomes: spiritual, physical, social and mental (Captari et al. 2018:1938). Fourth, they address the growing spiritual and religious struggles with the sacred, for instance, many people are asking theodicy questions: 'If God is both omnipotent and good, why has he allowed COVID-19 to devastate the world?' (Turner 2020:29). Consequently, some people have developed an absence of meaning in life, doubt and anger towards God, which can also be inked with mental health problems (Dein et al. 2020) and predict difficulties in psychosocial functioning (Sandage et al. 2020).

\section{Conclusion}

This article discussed the phenomena of theological education and the COVID-19 pandemic in Sub-Saharan Africa with specific reference to Malawi. Six main findings were established. First, the Covid-19 pandemic presents both challenges as well as opportunities for theological education in Africa. Second, the effectiveness of theological education in Africa contributes towards the future of Christianity on the continent. Third, the disruption that the novel coronavirus has caused to the provision of theological education in Africa challenges the dominant models of face-to-face teaching and even threatens the continued existence of theological institutions. Fourth, the COVID-19 pandemic provides opportunities for creativity and innovation which could ensure the survival and sustainability of theological education in Africa. This entails a shift from face-to-face teaching to online teaching and learning. Fifth, theological education can 2020 to NetAct members inviting them to attend the online theological education conference. make a tremendous contribution in countering misleading theologies that disregard the compliance of COVID-19 prevention measures and frightens people from taking COVID-19 vaccines. Sixth, theological education has the opportunity of constructing life-giving theologies in the following areas: the defence of human dignity and rights, curbing GBV, and addressing the growing challenges of mental health issues in Africa.

The main implication of this article is that the COVID-19 pandemic has impacted theological education in Malawi both positively and negatively. However, the prospect of theological education in navigating through the pandemic is twofold. First, it is imperative for theological education to construct life-giving theologies that provide guidance in dealing with the various aspects of the pandemic. Second, theological institutions and their leaders should come to terms with the indispensable and urgent need of shifting to online teaching and learning in Africa amid the ongoing COVID-19 pandemic.

\section{Acknowledgements Competing interests}

The authors have declared that no competing interest exist.

\section{Authors' contributions}

Dr J.H. Mawerenga participate in the conceptualisation, did the investigation and wrote the original draft. Prof. J.J. Knoetze participate in the conceptualisation, did some review and editing and fund the publication.

\section{Ethical considerations}

This article followed all ethical standards for a research without direct contact with human or animal subjects.

\section{Funding information}

This research received no specific grant from any funding agency in the public, commercial, or not-for-profit sectors.

\section{Data availability}

Data sharing is not applicable to this article as no new data were created or analysed in this study.

\section{Disclaimer}

The views and opinions expressed in this article are those of the authors and do not necessarily reflect the official policy or position of any affiliated agency of the authors.

\section{References}

Agang, S.B., Forster, D.A. \& Hendriks, H.J. (eds.), 2020, African public theology, Langham Publishing, Cumbria.

Amanze, J.N., 2009, 'Paradigm shift in theological education in southern and central Africa and its relevance to ministerial formation', International Review of Mission 98(1), 120-131. https://doi.org/10.1111/j.1758-6631.2009.00010.x 
Baron, E. \& Maponya, M.S., 2020, 'The recovery of the prophetic voice of the church: The adoption of a "missional church" imagination', Verbum et Ecclesia 41(1), 1-9. a2077. https://doi.org/10.4102/ve.v41i1.2077

Beukes, J.W., 2020, 'To be or not to be? A missional and practical theological perspective on being Church without walls amidst coronavirus disease 2019: A challenge or an opportunity?', HTS Teologiese Studies/Theological Studies 76(1), a6115. https://doi.org.10.4102/hts.v76i1.6115

Cahalan, K.A., 2005, 'Three approaches to practical theology, theological education, and the church's ministry', International Journal of Practical Theology 9(1), 64-94. https://doi.org/10.1515/IJPT.2005.005

Captari, L.E., Hook, J.N., Hoyt, W., Davis, D.E., McElroy-Heltzel, S.E. et al., 2018, 'Integrating clients' religion and spirituality within psychotherapy: A comprehensive meta-analysis', Journal of Clinical Psychology 74(11), 1938-1951. https://doi.org/10.1002/jclp.22681

Chilora, S., 2020, 'Peter Mutharika declares COVID-19 national disaster', The Times Group Malawi, 21 March, p. 1

Chitando, E., 2009, 'Equipped and ready to serve? Transforming theological and religious studies in Africa', paper presented at the Joint Conference of Academic Societies in the Fields of Religion and Theology, University of Stellenbosch, Stellenbosch, Session A, 22-26th June.

Chitando, E., Gunda, M.R. \& Togarasei, L., 2020, 'Introduction: Religion and development in Africa', in E. Chitando, M.R. Gunda \& L. Togarasei (eds.), Religion and development in Africa, pp. 13-36, University of Bamberg Press, Bamberg.

Chiuta, W., 2020, 'No Corona Virus lockdown in Malawi as court maintains injunction', Nyasa Times, 28 April, p. 1.

'Coronavirus: France racism row over doctors' Africa testing comments', BBC News, 03 April, 2020, viewed 28 July 2021, from https://www.bbc.com/news/worldApril, 2020, view
europe-52151722

Cotterill, J., 2020, 'Opposition takes power in Malawi after historic election rerun: Former Pentecostal pastor Lazarus Chakwera defeats Peter Mutharika in presidential poll', Financial Times, 28 June, p. 3.

Coughlin, S.S., 2012, 'Anxiety and depression: Linkages with viral diseases', Public Health Reviews 34(2), 7. https://doi.org/10.1007/BF03391675

De Gruchy, J., 2007, Public theology as Christian witness: Exploring the genre', International Journal of Public Theology 1(1), 26-41. https://doi. org/10.1163/156973207X194466

Dein, S., Loewenthal, K., Lewis, C.A. \& Pargament, K.I., 2020, 'COVID-19, mental health and religion: An agenda for future research', Mental Health, Religion \& Culture 23(1), 1-9. https://doi.org/10.1080/13674676.2020.1768725

Del Castillo, F.A., Biana, H.T. \& Joaquin, J.J.B., 2020, 'Church in Action: The role of religious interventions in times of COVID-19', Journal of Public Health 42(3), 633-634. https://doi.org/10.1093/pubmed/fdaa086

Dlamini, J., 2020, 'Gender-based violence, twin pandemic to COVID-19', Critical Sociology 47(4-5), 583-590. https://doi.org/10.1177/0896920520975465

Docrat, S., Besada, D., Cleary, S., Daviaud, E. \& Lund, C., 2019, 'Mental health system costs, resources and constraints in South Africa: A national survey', Health Policy and Planning 34(9), 706-719. https://doi.org/10.1093/heapol/czz085

El Bouhali, C. \& Rwiza, G.J., 2017, 'Post-millennium development goals in sub-Saharan Africa: Reflections on education and development for all', in E. Shizha \& N. Makuvaza (eds.), Re-thinking postcolonial education in sub-Saharan Africa in the Makuvaza (eds.), Re-thinking postcolonial education
21st century, pp. 13-31, Brill Sense, Rotterdam.

Franco, I.B. \& Derbyshire, E., 2020, 'SDG 4 quality education', in I.B. Franco, T. Chatterji, E. Derbyshire \& J. Tracy (eds.), Actioning the global goals for local impact, pp. 57-68, Springer, Singapore.

Gadabu, A., 2020, 'Malawi's response risk factors and preparedness for COVID-19', North American Academic Research 3, 44-66.

Hendricks, J., 2020, email, 02 September, HJH@sun.ac.za

Houston, B., 2009, 'Missiological and theological perspectives on theological education in Africa: An assessment of the challenges in evangelical theological education', paper presented at the Joint Conference of Academic Societies in the education', paper presented at the Joint Conference of Academic Societies in the
Fields of Religion and Theology, University of Stellenbosch, Stellenbosch, Session Fields of Religion and

Hunter, E., 2020, 'Responding to the COVID-19 crisis: Moving from desperation to hope in theological education', Insights Journal for Global Theological Education $6(1), 21-30$

Hutapea, A.A., 2021, 'Disastrous theology and its contribution in encountering covid-19 pandemic', International Journal of Science and Society 3(2), 98-112.

Isichei, E., 1995, A history of Christianity in Africa: From antiquity to the present, Wm. B. Eerdmans, Grand Rapids, MI.

Kaponda, C., 2020, 'No COVID-19 lockdown still threatens livelihoods and trade in Malawi' [blog], Africa at LSE, viewed 30 July 2021, from https://blogs.Ise.ac.uk/ africaatlse/2020/09/25/no-covid19-lockdown-threatens-livelihoods-tradeafricaatlse/202

Kaunga, S.B., 2020, 'How have Malawi's courts affected the country's epidemic response?' [blog], Africa at LSE, viewed 30 July 2021, from https://blogs.Ise.ac.uk/
africaatlse/2020/11/13/how-have-malawis-courts-law-affected-epidemic-response/

Kayange, A.K., 2019, 'E-learning encounters in Malawi higher education institutions', International Journal for E-Learning Security (IJeLS) 8(1), 592-603. https://doi. org/10.20533/ijels.2046.4568.2019.0074

Kloppers, E., 2020, 'Sounding the sacred in the age of fake news-Practical theology reflecting on the public sphere', HTS Teologiese Studies/Theological Studies 76(2), 6. https://doi.org/10.4102/hts.v76i2.6131

Koenig, H.G., 2020, 'Maintaining health and well-being by putting faith into action during the COVID-19 pandemic', Journal of Religion and Health 59, 2205-2214. https://doi.org/10.1007/s10943-020-01035-2
Maluleka, K.J., 2019, 'Indigenous African philosophy of Ubuntu as a foundation for a conducive environment for culturally responsive teaching and learning in South Africa', paper presented at the International conference new trends in teaching Africa', paper presented at the International conference new trends in teaching and learning, Barcelona, Spain, 5-7 September, viewed 10 September 2021,
https://www.dpublication.com/wp-content/uploads/2019/09/19-5299.pdf

Mandala, M. \& Changadeya, W., 2021, 'The fight against corona virus in Malawi: A review of challenges and opportunities in the health sector', Malawi Journal of Science and Technology 13(1), 1-10.

Matemba, Y.H., 2011, 'Perspectives on theological education in Malawi', Arts and Humanities in Higher Education 10(3), 329-347. https://doi. org/10.1177/1474022211408036

Mkonto, P.N., 2010, 'The development and evaluation of a learning styles assessment tool for the South African higher education context', PhD dissertation, University of the Western Cape.

Mosterd, N., 2019, email 20 August, nicom@absamail.co.za

Mpofu, B., 2021, 'Transversal modes of being a missional church in the digital context of COVID-19', HTS Theological Studies 77(4), 1-6. https://doi.org/10.4102/hts. v77i4.6341

Mpungose, C.B., 2020, 'Emergent transition from face-to-face to online learning in a South African University in the context of the Coronavirus pandemic', Humanities and Social Sciences Communications 7(1), 1-9. https://doi.org/10.1057/s41599020-00603-x

Msoma, P., 2021, Facebook page, viewed 18 January 2021, from https://www. facebook.com/paul.msoma

Mwandumba, J.V., 2015, 'Church-state relations in Malawi. The Roman Catholic Church as an Agent of Political Reform (From 1992 Until Present)', Danubius 33(2), 77-91.

Mwaniki, L., 2020, Shared conversations 3: Gender, theologies and covid-19 webinar resources, viewed 30 July 2021, from http://sidebysidegender.org/covid_theologies/

Nations Publications Limited, n.d., News update [Facebook], viewed 10 June 2021, from https://www.facebook.com/445893998764829/posts/news-updatethe-ccap-general-assembly-says-it-will-maintain-its-seatingcapacity/3433789976641868/

NetACT, n.d., viewed 18 October 2021, from http://www.sun.ac.za/english/faculty/ theology/Pages/NetACT.aspx

NIP, n.d., viewed 18 October 2021, from https://netact.org.za/wordpress/nip/

Nyasa Times Reporter, 2021, 'Kenani's Covid-19 initiative appeals for tax waiver on items to be bought', Nyasa Times, viewed 19 January 2021, from https://www. nyasatimes.com/kenanis-covid-19-initiative-appeals-for-tax-waiver-on-items-tobe-bought/

Nyasulu, J.C.Y., Munthali, R.J., Nyondo-Mipando, A.L., Pandya, H., Nyirenda, L., Nyasulu, P.S. et al., 2021, 'COVID-19 pandemic in Malawi: Did public sociopolitical Nyasulu, P.S. et al., 2021, 'COVID-19 pandemic in Malawi: Did public sociopolitical events gatherings contribute to its first-wave local transmission?', International
Journal of Infectious Diseases 106, 269-275. https://doi.org/10.1016/j. Journal of Infect

Onyejekwe, C.J., 2004, 'The interrelationship between gender-based violence and HIV/AIDS in South Africa', Journal of International Women's Studies 6(1), 34-40.

Patel, P., Adebisi, Y.A., Steven, M. \& Lucero-Prisno III, D.E., 2020, 'Addressing COVID-19 in Malawi', The Pan African Medical Journal 35(2), 71. https://doi.org/10.11604/ pamj.supp.2020.35.2.23960

Penner, P., 1997, 'Theologische Ausbildung-eine Verpflichtende Mission: Faktoren zur Bestimmung von Leitlinien für theologische Ausbildung in der GUS', PhD thesis, UNISA, Pretoria.

Phiri, I.A., Werner, D., Djomhoué, P., Amanze, J., Owino, K., Phiri, S., Mbiti, J.S. Karamaga, A., Botman, H.R., Tveit, O.F. and Oduyoye, M.A., (eds.), Handbook of theological education in Africa, Regnum Books International, Oxford.

Polizzi, C., Lynn, S.J. \& Perry, A., 2020, 'Stress and coping in the time of Covid-19: Pathways to resilience and recovery', Clinical Neuropsychiatry: Journal of Treatment Evaluation 17(2), 59-62.

Sandage, S.J., Rupert, D., Stavros, G. \& Devor, N.G., 2020, Relational spirituality in psychotherapy: Healing suffering and promoting growth, American Psychological Association, Washington, DC.

Semo, B.W. \& Frissa, S.M., 2020, 'The mental health impact of the COVID-19 pandemic: Implications for sub-Saharan Africa', Psychology Research and Behavio Management 13, 713-720. https://doi.org/10.2147/PRBM.S264286

Singh, J.A., 2020, 'The case for why Africa should host COVID-19 candidate vaccine trials', The Journal of Infectious Diseases 222(3), 351-355. https://doi. org/10.1093/infdis/jiaa303

Tengatenga, J., Tengatenga Duley, S.M. \& Tengatenga, C.J., 2021, 'Zimitsani Moto: Understanding the Malawi COVID-19 Response', Laws 10(2), 1-20. https://doi. org/10.3390/laws10020020

The Inclusive Internet Index, 2021, viewed 28 July 2021, from https:// theinclusiveinternet.eiu.com/explore/countries/MW/

Turner, B.S., 2020, 'Theodicies of the COVID-19 catastrophe', in J.M. Ryan (ed.) COVID-19: Global pandemic, societal responses, ideological solutions, pp. 29-42, Routledge, London.

United Nations, 2020, Policy brief: Education during COVID-19 and beyond, United Nations, New York, NY.

UN Women, 2020, The shadow pandemic: Violence against women and girls and COVID-19, viewed 10 September 2021, from https://www.unwomen.org/en/ news/in-focus/in-focus-gender-equality-in-covid-19-response/violence-againstwomen-during-covid-19

Van der Merwe, D., 2016, 'From Christianising Africa to Africanising Christianity: Some hermeneutical principles', Stellenbosch Theological Journal 2(2), 559-587. https://doi.org/10.17570/stj.2016.v2n2.a25 
Van Deursen, A.J. \& Van Dijk, J.A., 2019, 'The first-level digital divide shifts from inequalities in physical access to inequalities in material access', New Media \& Society 21(2), 354-375. https://doi.org/10.1177/ 1461444818797082

Vidler, A.R., 1961, The Church in an Age of Revolution: 1789 to the present day, Penguin Books, Westminister, London. (The Pelican History of the Church).

Vorster, K., 2006, 'Christian attitude and the human dignity of women', Studia Historiae Ecclesiasticae 32(2), 229-268.
Weissman, F., 2021, MSF Covid-19 response in Malawi, viewed 28 July 2021, from https://www.msf.org/malawi-overwhelmed-second-wave-coronavirus-covid-19

Wodon, Q., 2014, 'Faith-inspired schools in Sub-Saharan Africa: An introduction to the summer 2014 issue', The Review of Faith \& International Affairs 12(2), 1-4. https://doi.org/10.1080/15570274.2014.918754

Xiang, Y.T., Yang, Y., Li, W., Zhang, L., Zhang, Q., Cheung, T. et al., 2020, 'Timely mental health care for the 2019 novel coronavirus outbreak is urgently needed', The Lancet Psychiatry 7(3), 228-229. https://doi.org/10.1016/S2215-0366(20)300046-8 